\title{
Translanguaging Used By English Teacher at Vocational Schools Medan
}

\author{
Masitowarni Siregar \\ Universitas Negeri Medan, Indonesia \\ siregarmasitowarni@yahoo.co.id
}

\begin{abstract}
The objective of this endeavor was to examine the utilization of translanguaging by vocational English teachers in Medan. The emphasis of the study was to identify the English instructor of vocational schools in Medan translated instruction in classroom. This endeavor was implemented by utilizing descriptive qualitative technique. The data of the research were the talk of English teacher instructions of vocational schools in Medan. The data were taken and collected from recorded and videos of the English teacher of vocational schools in Medan. The data were analyzed by applying the inductive model proposed by Miles, Huberman \& Saldana (2014) such as data condensation, data display, and conclusion drawing or verification. The results of the study showed that teacher used English first and continued in using Indonesian language to make the students comprehend about the conversation in the classroom. Thus, the students are not bored and interest to study English.
\end{abstract}

\section{Keywords}

translanguaging, English

teachers, vocational schoods

\section{Introduction}

The use of language is indispensable in communicating from one person to another person and from one group of people to another group of people. This is true in terms of communication in the classroom in Indonesia. In the context of foreign language teaching of course the teacher and the students are exposed in two kinds of language namely the language of the students and teacher and the language being studied.

In teaching English as a foreign language an English teacher has to find ways how to communicate the lesson being studied by mixing the language. In one side the teacher has to introduce the new language in other side the teachers has to make sure that the students understand what is being said. Usually the English teachers make initiatives by translating the language. Sometimes the teacher speak in English first followed by translation. Other time the teacher speak in Bahasa or local language and then translate into English.

Based on observation English teacher has to accommodate foreign language students language. In remote area with the students speak local language the teacher even has to speak ini local language because the students hardly speak Bahasa. This is a very challenging situation. If the teacher is from the some ethnic the communication will be easy. The hard thing is if the teacher and the students are from different ethnic. For example if the teacher is Bataknese and she teaches in the area where Javanese live although it is still in the Sumatera Utara Province. The situation will be difficult. When the teacher for example teach young coconut and the students shouts saying degan, so the teacher has to translate from their local language inti bahasa and into English. This where the context of translanguiging starts.

Basically Translanguaging cannot be avoided in the context of second language and foreign language teaching. Translanguaging help the communication in the classroom among students and between teacher and students. The consequences are that the teacher has to be a 
good translator to avoid the misconception of meaning being communicated. Owen (2002: 2) states "The use of translation, as a moment's reflection will confirm, has been a fundamental part of language teaching since the very beginning. Indeed, it must be the oldest languageteaching tool of all."

Based on the preliminary data found from vocational schools in Medan, English is very important for the students because it can support the students who will work directly after graduation as the main goal of vocational schools. Not only that, but because vocational schools are also prefer improving skills to increasing many theories. Therefore, studying English at vocational schools are more challenges to make the students to be able to speak even in the other schools are also like that. However, vocational schools are demanded to create all the students to be able to practice English as one of main criteria in seeking for a job later.

However, the students in vocational school are still lack of ability in understanding English because they prefer focusing on their mayor to focusing English. Then, the important thing in learning English is practice. Therefore, the teachers try to practice English in the class by using English to communicate with the students. However, many of students are bored because they do not understand what the teachers said. Furthermore, the students think that English is very difficult and do not have confidence to speak because they are afraid to make a mistake.

Based on the problems found in that school, the teachers try to use another method to teach English in vocational schools of Medan. The teachers try to encourage the students by practice the English but still maintain the students' attention so that they can understand what the teacher said to them. Translation is a teaching method used by the teachers to solve the problems in English class of vocational schools in Medan.

Garcia (2009:140) argues that translanguaging is used to facilitate communication where the language of speaker and the hearer is not the same. Translanguaging is in the context of teacher used the students mother tongue to help the process of teaching and learning second and foreign language. Therefore, the study aimed to analyze translanguaging used by English teachers of vocational schools in Medan.

\section{Review of Literatures}

\subsection{The Nature of Translation}

Based on Larson (1991) translation is an activity related to the hypothesis that is possible to understand the massage of a text from its forms and reproduces that meassage with the natural way of expressing the same meaning in the target language. Based on explanation above, the translator somehow may put an end the true message of the source language to get a reasonable sense of the target language. (Siregar, 2020)

There are many schools of tough about translation. As time develops the translation nature is different. In Oxford Advanced Learner's Dictionary, translation defines as the process of changing something that is written or spoken into another language. This definition is very basic. This is the starting point to discuss further about the nature of translation

Newmark points out that translation means finding out the message of a text in the source language and express that meaning into the target language. The translation is regarded as good if the meaning of the source language understandable. In other words the reader can get the point being translated. 
According to Larson "Translation is basically a change of form. When we speak of the form of the language, we are referring to the actual words, phrases, clauses, sentences, paragraphs, etc., which are spoken or written. These forms are referred to as the surface structure of a language. It is the structural part of language which is actually seen in print or heard in speech. During translation process the translator has to make sure that meaning is carried out including the form of the language. This means if the source language has the element of word, phrases and sentences, the target text has to maintain that as natural as possible.

Nida and Tiber assumes that translation is the process of bringing the meaning of one text in the source language to the text of target language. The meaning has to be maintained. This means that Nida and Tiber are in the opinion that translating is the process of bringing the meaning of source language as closest as possible with the meaning in the target language. So, translation is about the meaning not the form.

\subsection{Characteristics of Translation}

There are some of distinctive features of translation such as, (1)translation is transferring meaning from source text into the target text (2) translation emphasizes on written notion or text; (3) translation reproduces the meaning not the form of the text ; (4) translation need procession and rehearsal (5) The target material should contain similar notion or essence with the source material; (6) Target material should utilize set phrase to maintain the message of the source text ; and (7) Target language material utilize language parallel.

There are many aspects contributed to translation skills. Pym in Stuart Campbell states that translation skill are made of many aspects to be able to understand the meaning of first language and reprove that meaning into the target language. The translator has to make sure that he reproduces the same notion.

The many aspect contributed to translation skills are knowledge of the source text, knowledge of the material or discipline, knowledge about the target language. The translator knowledge of the notion of source text should be similar with that of target text to be able to transfer the meaning from the source text to the target text.

\subsection{Function of Translation}

Function of translation basically is to enable people of one community understand the meaning of written material in other community language. By this there will be transfer of knowledge, information, values and norms. By this a translator should be able to understand the meaning of target language and reproduce the meaning in the other language.

In conclusion translation could cover a very broad context including formal and informal text. The text translated could also cover many subjects including various kinds of science: economy, forestry, law, management, medicine, social, fiction, religious texts.

\subsection{Types of Translation}

Basically translation goes into two broad distinction; literal translation and free translation. Kinds of translation can also be made based on definition. Nida and Taber proposed two kind of translation; literal and dynamic translations. The dynamic translations proposed by Nida and Taber seem to be similar with Larson's meaningful translation.

Larson argues there are two basic types of translation namely literal and idiomatic translation. Literal translation is translating mainly by observing the form of the source text. In form based translation the translator tends to maintain the form of the source texts. The translator also seems keep the structure of the text and logicality of the text. 
Nowadays the existence of translation keeps developing. The need for translation cannot be avoided. To understand many new books on one country innovation, other country just make the attempt to translate them. Not to mention now there atre many technological advancement and economic knowledge. .

This situation are realized by the countries so that there are many school of translation now developed. In Indonesia there are study programs producing translators starting from undergraduate, Master and Doctoral degree.

Following the developmental growth of translation education in Indonesia, a number of basic notions for gaining the skills to be a translators are important to emphasized namely, (1) Translation knowledge and skill derived from many distinctive schools of disciplines that should be accommodated in the universities (2) Translation learning is a very deliberate attempt to produce skillful translators to function well at the society ; (3) Students who learn translation may result in some levels ok knowledge and skills since they are coming from different level of accommodating knowledge and skills to be translators and (4) University should have clear concept of assessment of translation training. Many efforts should be made to ensure the quality of students' translation. Porto folio and workshop in many translation institution are some ways that can be done.

\subsection{Translanguaging}

According to Yuvayapan (2019) mastering of more than one language resulting in academic interest around the teaching methods in bilingual education. It is well-noted that bilinguals have the ability to shift flexibly from one language to another, which paves the way for the employment of various methods in classrooms. Yuvayapan (2019) also stated that Language is a kind of integrated system for bilinguals/multilingual to be negotiated for communicative purposes. This system requires a multi competence needed in separate languages in one's competencies.

Based on Garcia \& Wei (2014), translanguaging propose society with more than one languages competency which result in manifold advantages. It ensures a deeper understanding of content as well as enhancing the lacking of language by scaffolding with the dominant one. In addition, Baker (2011) stated there are four benefits of translanguaging such as, (1) translanguaging produce students with a better comprehension and knowledge on the subject being studied. It may promote a deeper and fuller understanding of content; (2) transkills in their lower language skills; (3) translanguaging help accommodating homeschool collaboration; and (4) translanguaging may help the students to improve their second language and foreign language competency all together with subject knowledge.

\section{Research Methods}

This study was established by implementing descriptive qualitative design. The focus of this study was to analyze translanguaging used by English teachers of vocational schools in Medan. Newmark (2001) and Larson (2003). The data of the research were the utterances from English teacher instructions of vocational schools in Medan. The data were taken and collected from recorded and videos of the English teacher of vocational schools in Medan. The data were examined by using the inductive model proposed by Miles, Huberman \& Saldana (2014). According to Miles \& Saldana, three phases were taken in excecuting the design: data condensation, data display, and conclusion drawing or verification. 


\section{Discussion}

Garcia (2009:140) is in opinion that translanguaging is notion done by bilinguals of obtaining distinctive linguistic features or various designs of things elaborated as selfgoverning languages, with the purpose of augmenting the ability to communicative competence. Translanguaging becomes one mode of utilizing the learners' mother tounge to facilitate the learners in comprehending the subject being learnt in teaching and learning process. Translanguaging is expected to maximize the learners' knowledge, attitude and skills in the pedagogical activities of second and foreign language teaching.

Based on data found in English teachers of vocational schools in Medan, the following below are the teachers' utterance in teaching English.

1. What is your mayor?

Kalian jurusannya apa?

2. Cobalah try to speak bahasa Inggris with your boss!

3. Do you understand what I said dear?

Ananda memahami apa yang Ibu sampaikan?

4. Please observe your book, there are a number of things.

Ananda silahkan memperhatikan buku kita, disitu ada banyak benda kan?

5. I want to make your duty

Ibu akan buat tugas kamu

6. Ok, give applause

Tepuk tangan.,,

7. I think it is enough for our lesson today

Saya rasa sudah cukup pelajaran kita hari ini

8. You can collect all your book, your exercise book in front of our class or on my table, okay.

Kamu bisa mengumpulnya, latihan tadi di depan atau diatas meja saya

9. At present

Saat ini..

10. Teacher:'Sharpener' itu artinya bukan kerokan, tapi 'rautan'

11. We have already finished today, see you next week!

Kita sudah selesai, sampai jumpa minggu depan ya!

\section{Data B}

T : Assalamu'alaikum

Sts : Wa'alaikumussalam

$\mathrm{T}$ : Good Afternoon Students.

Sts : Good Afternoon, Bu.

$\mathrm{T}$ : Who is absent today? Siapa yang absen?

Sts : D, Bu.

$\mathrm{T}$ : Only her?

Sts : BS, Bu.

$\mathrm{T}$ : Ok, both of them ya?

Ok, let's begin our lesson with lafadz basmallah.

Sts : Bismillahirrahmanirrahim.

$\mathrm{T} \quad$ : How are you feeling today?

Sts : We are fine, Bu. And you? 
$\mathrm{T} \quad$ : Fine, too. Thank you. Now, we learn new topic analytical exposition text. Do you

know analytical exposition text? Apakah ananda tahu teks ini?

Sts : Ga, Bu.

T : Yakin? Are you Sure?

Kalau di dalam pelajaran Bahasa Indonesia ini teks eksposisi.

Sts : Oh, sudah Bu.

T : Ok, Please clean this board. (After 2 minutes). Thank you. Nah, Analytical Exposition Text merupakan teks yang menerangkan nuansa science dalam kegiatan keseharian. Therefore, it is a text that explain an occurance around by an author.

Misalnya merokok "smoking", contoh yang lain "handphone - The danger of car". Narkoba "drugs". Bagaimana di sekitarmu?

Sts : Ada Bu.

$\mathrm{T} \quad$ : berdampak buruk nggak?

Sts : Ada Bu.

$\mathrm{T} \quad$ : Siapa yang bisa menambahi fenomena di lingkungan sekitar?

St1 : Penebangan hutan, Bu.

$\mathrm{T} \quad$ : Yes. Woods Cutting. Any else? Ada lagi? Coba berpikir lagi!

St3 : Bancana alam, bu?

St2 : Kebakaran, bu?

$\mathrm{T}$ : That's all the occurances around us. Bencana alam "natural disaster", Kebakaran. Nah, itulah tentang teks analytical exposition ini. Hari ini kita belajar bagian dari analitikal eksposisi. Ada tiga unsur. Pertama thesis. Thesis memperkenalkan ide apa yang hendak disampaikan pada satu paragraph.. Fungsi thesis, siapa yang tahu?

Sts : Pembuka paragraf, Bu.

$\mathrm{T} \quad$ : . Nah, setelah thesis, ada yang namany arguments. Arguments apa? What is argument?

Sts1 : Pendapat, Bu.

$\mathrm{T} \quad$ : Iya, ide. Ide yang mendukung thesis yang disampaikan sebelumnya. Setelah si penulis membuat thesis atau main ideanya, penulis harus membuat pendapat untuk menguatkan thesisnya. Terakhir, kesimpulan.

Inilah komponen analytical exposition.

Ok, now! . Sekarang bekerja dalam kelompok ya.

Kita akan melihat unsur atau elemen yang terdapat pada teks atau paragraf analytical exposition ini.

Sts : Kami kerjakan di buku Bu?

$\mathrm{T}$ : Di kertas. I give you 15 minutes to see those elements of the text. The text is about "Using mobilephone can be dangerous".

Sts : Yes, Mam.

$\mathrm{T} \quad$ : Finish ?

Sts : Yes, Mam.

T : Ok, D. Can you find the thesis? Sebutkan theisisnya?

St2 : Pemakaian HP berlebihan berbahaya?

$\mathrm{T} \quad$ : Yes. Good. Continue to group 2. Now find the arguments

St3 : Ada 3 argumentnya Bu.

$\mathrm{T}$ : Iya. Ada 3. There are 3 arguments in the text. Yang mana sayang?

$\mathrm{T}$ : Iya. Ingat aja tandanya, kalau argumennya lebih dari satu, biasanya ada penandanya. There is a clue. For example, The first, next, last.

Sts : Iya, bu.

$\mathrm{T} \quad$ : The last, which one is the reiteration? 
St4 : Saya, Bu.

T : Ok, read please. Bacalah nak.

Ok. Sudah mengerti topic analytical exposition ini?

Sts : Sudah, Bu.

Ok. I think that's all for today. And let's close with Hamdalah.

Sts : Alhamdulilahi rabbil 'alamiin.

$\mathrm{T} \quad$ : Assalamu'alaikum warah matullahi wabara katuh

Sts : Wa'alaikumussalam warah matullahi wabara katuh

From the data found in the conversation in the classroom, it was found out that the teacher used Translanguaging in teaching English in vocational schools of Medan. Sometimes, the teacher used English first and continued in using Indonesian language. However, the teacher also translated it into Indonesian language. At other cases, the teachers used Bahasa without translating. This is purely to help the students understand the concept being learned. This way, make the student easier to understand what teacher said in front of the class. This can be seen from the observation of the students' response to the teachers' talk in the classroom by observing the students' responses toward the teacher in the classroom. Since, if the teacher used full English in the classroom, it was difficult to the students in comprehending English learning.

It was related to Canagarajah (2011) stated that translanguaging proved to be efficient to accommodate the comprehension of the students both in learning second language as well as foreign language.

\section{Conclusion}

English teachers of vocational schools in Medan often used translanguaging in making the students understand about what the teachers mean in the classroom. Thus, the students are not bored and interest to study English. Since learning English is not only about studying grammar but the learners must practice themselves. This way, make the student easier to understand what teacher said in front of the class. This way, make the student easier to understand what teacher said in front of the class. This can be seen from the observation of the students' response to the teachers' talk in the classroom by observing the students' responses toward the teacher in the classroom. Since, if the teacher used full English in the classroom, it was difficult to the students in comprehending English learning . The result of the study related toward the previous study which was Canagarajah (2011) who stated that translanguaging proved to be efficient to accommodate the comprehension of the students both in learning second language as well as foreign language.

Furthermore, by using translanguaging it will increase the learners competency the students' ability in understanding English because the students of vocational schools prefer focusing on their mayor to focusing English. Then, the important thing in learning English is practice. Therefore, the teachers try to practice English in the class by using English to communicate with the students. Since the vocational schools are demanded to create all the students to be able to practice English as one of basic criteria in seeking for a job later. 


\section{References}

Arikunto. (2006). Prosedur Penelitian Suatu Pendekatan Praktik. Jakarta: Rineka Cipta.

Aswita, Effi Lubis. (2012). Metode Penelitian Pendidikan. Medan: Unimed Press

Baker, C. (2011). Foundations of bilingual education and bilingualism. New York: Mc Naughton

Campbell, Stuart. (1998). Translation into the Second Language. America: Addison Wesley Longman Limited.

Canagarajah, S. (2011). Translanguaging in the classroom: Emerging issues and research in pedagogy. Applied Linguistics Review, 2, 1-28.

Farida RepelitaWati. (2016). My Translation My Adventure, Medan: Universitas Islam Negeri Sumatera Utara

García, O.,\& Wei, L. (2014). Translanguaging: Language, bilingualism and education. Basingstoke:

Gunn Ltd.

Khoirul Hasyim.(2102).The Process of Translation II. https://khoirulhasyim.wordpress.com/2012/11/11/the-process-oftranslation-ii/. Accesed on 2 February 2020. At 10.17 Istiqomah,

Moleong, L.J. (2001). Metodologi Penelitian Kualitatif. Bandung: PT. Remaja Rosda Karya.

Moleong,L.X. (2004).Metodologi Penelitian Kualitatif. Bandung: PT. Remaja.

Muchtar. (2015). Penerjemahan, Teori, Praktik, dan Kajian. Medan: Batongjaya

Nababan, Mangatur. (2012). "Pengembangan Model KualitasTerjemahan," Kajian Linguistik dan Sastra. Vol. 24 No.1: 39-57. Nida, dkk. 1983.

Newman and Summer. (2007). Perspectives of communication and communicative competence. New Delhi: Concept Publishing company. Palgrave Macmillan.

Rasman. (2018). To Translanguage or not to Translanguage? the Multilingual Practice in an Indonesian Efl Classroom. Indonesian Journal of Applied Linguistics. Vol. 7 No. 3, January 2018, pp. 687-694.

Simatupang, Maurits D.S. (2000). Pengantar Teori Terjemahan, Jakarta: Universitas Indonesia

Siregar, M. (2020). Pedagogical Translation Use by Scientific Approach in Teaching English. Budapest International Research and Critics in Linguistics and Education (BirLE) Journal. P. 111-119.

Suciati, Ending. (2010). Penerjemah dan Penelitian Terjemahan. Jurnal Kajian Ilmiah $\begin{array}{llll}\text { Kebahasaan dan } & \text { Kesusastraan. } & \text { Nol.1. }\end{array}$ .http://download.portalgaruda.org/article.php?article=116473\&val=5319. Accesed on 29 October 2018 at 16.42

Sugiyono. (2009). Metode Penelitian Pendidikan, Bandung: Penerbit Alfabe

Sumarsih, Siregar, Bahri, and Sanjaya. (2014). Code Switching and Code Mixing in Indonesia: Study in Sociolinguistics. English Language and Literature Studies. Vol. 4, No. 1.

Tohirin. (2012). Metode Penelitian Kualitatif dalam Pendidikan dan Bimbingan konseling. Jakarta: PT Grafindo Persada

Tohirin. (2012). Metode Penelitian Kualitatif dalam Pendidikan dan Bimbingan konseling. Jakarta: PT Grafindo Persada

Yuvayapan, Fatma. (2019). Translanguaging in EFL classrooms: Teachers' perceptions and practices. Journal of Language and Linguistic Studies. Vol. 15(2) Page 678-694. 